Volume and Issues Obtainable at Center for Sustainability Research and Consultancy

Journal of Accounting and Finance in Emerging Economies

ISSN: 2519-0318ISSN (E) 2518-8488

Volume 4: Issue 2 December 2018

Journal homepage: publishing.globalcsrc.org/jafee

\title{
Impact of Financial Literacy and Parental Socialization on the Saving Behavior of University Level Students
}

\author{
${ }^{1}$ Junaid Afsar, ${ }^{2}$ Ghulam Mujtaba Chaudhary, ${ }^{3}$ Zafar Iqbal, ${ }^{4}$ Muhammad Aamir \\ ${ }^{1}$ Department of Business Administration, University of Kotli Azad Jammu \& Kashmir Pakistan \\ E-mail:junaidafsar5@gmail.com \\ ${ }^{2}$ Department of Business Administration, University of Kotli Azad Jammu \& Kashmir Pakistan \\ E-mail: adfuajk@yahoo.com \\ ${ }^{3}$ Department of Business Administration, University of Kotli Azad Jammu \& Kashmir Pakistan \\ Email: zafar.iqbal@uokajk.edu.pk \\ ${ }^{4}$ Department of Commerce, Bahauddin Zakariya University, Multan Pakistan. \\ ARTICLE DETAILS

\section{History} \\ Revised format: $\quad$ Nov 2018 \\ Available Online: Dec2018

\section{Keywords} \\ Financial Literacy, \\ Parental Socialization, \\ Saving Behavior \\ JEL Classification: \\ G10,O16

\begin{abstract}
This is an explanatory study on the impact of financial literacy and parental socialization on the saving behavior of university level students. Using primary data collection method, 400 questionnaires were distributed to the students of universities across Pakistan. Pearson correlation and multiple regression analysis are employed by using SPSS. Our results demonstrate that financial literacy and parental socialization positively influence the saving behavior of students. Our result revealed that the students who have financial literacy exhibit more saving behavior as compared to others who do not have financial knowledge. It is also concluded that the student willingness to save increased due to receiving financial education from their parents.
\end{abstract}

(C) 2018 The authors, under a Creative Commons Attribution-

NonCommercial 4.0

Corresponding author's email address: junaidafsar5@gmail.com

Recommended citation: ${ }^{1}$ Afsar, J. ${ }^{2}$ Chaudhary, G.M. ${ }^{3}$ Iqbal, Z. ${ }^{4}$ Aamir, M. (2018). Impact of Financial Literacy and Parental Socialization on the Saving Behavior of University Level Students. Journal of Accounting and Finance in Emerging Economies, 4(2)133-140

DOI: $10.26710 /$ jafee.v4i2.526

\section{Introduction}

Over the few past decades, savings are playing a major role in the economic development of the countries. Saving is the portion of income which is not spent on current consumptions. The consumption pattern of individuals determines their savings decisions (Browning \& Crossley, 2001; Baidoo, Boateng \& Amponsah, 2018). Saving is considered as a major factor that affects the economic growth of developing countries (Jagadeesh, 2015). In developing countries, saving is an essential element of households' welfare. For people and family units, savings give security against future crises while for national savings it gives resources that are required for the development of the country (Gedela, 2012; Jagadeesh, 2015). Savings are essential for the economic growth of country because if the savings rate is low, then the investment will also be low leading to the low capital formation. According to Horrod (1939) and Domar (1946), the savings rate and the ability to save help out to determine the speed of economic growth 
because an increase in the saving rate will lead to an increase in the rate of investments in the countries and therefore it stimulates economic growth of countries.

National Savings are essential for accomplishing high economic growth (Jagadeesh, 2015; Auerbach, \& Kotlikoff, 1983). An increase in the rate of saving can bring more investments (Cheema et al., 2018). It will finally lead to industrial growth, business era, change in the nature of items, stable costs, and higher growth (Ayadi, Ben Omrane, Lazrak, \& Yang, 2018). The savings of household and individuals are the essential segment of national saving in both developed and developing nations (Ayadi et al., 2018). During the 1960s, the national savings rate of Pakistan was around 10 percent of GDP and it increased to $15 \%$ in 2000s but after that it continuously declined. The saving rate in Pakistan is unfavorable in comparison to neighboring countries. The average saving rate of last five year was $31.9 \%$ in India, in Sri Lanka 24.5\% and in Bangladesh 29.7\% (SBP, 2016). When people save their money in different financial institutions then they will have more reserves. Due to increase in reserves, these institutions will give loans on the low interest rate for investment purpose. This aspect will enhance investment level and the economic growth in the country (Ahmed, 2015).

The best way to increase the national saving rate is to encourage the individuals for savings. The financial literacy can be provided to individuals through different educational programs and seminars. This will increase their knowledge and encourage them for making future financial plans, and pick the most reasonable financial instrument to accomplish and achieve their financial objectives.

To assess the saving behavior, several studies have been conducted in Pakistan (Khan, Hasan, Malik, \& Knerr, 1992; Mehmood \& Qasim, 1992; Nasir, Khalid \& Mehmood, 2004; Ahmed, 2015; Cheema, Saleem ur Rehman \& Atif, 2018). Akhtar (1987) analyzed the impact of dependency, urbanization, education on household savings. Also, Iqbal (1993) analyzed the impact of income level, domestic interest rate, domestic credit, foreign interest rate, private capital outflow, terms of trade, inflation rate, dependency ratio, worker's remittances, net foreign capital outflow, real wage rate, export earnings and debt service on saving behavior. Azhar (1995) worked on the determinants of savings in the rural area. Shaikh (2012) analyzed the impact of income, exports, debt, government expenditure and inflation on national saving.

In most of the studies, it is concluded that saving is an important component of an economy (Cheema et al., 2018). The higher level of savings can stimulate investment in the economy. Many factors can influence the savings behavior of university level students. The financial literacy and parental socialization are among such factors (Sarpong- Danquah, Gyimah, Poku, \& Osei-Poku, 2018). The exact identification of such factors can facilitate in boosting savings and mobilize these for efficient utilization. How financial literacy and parental socialization can affect the saving behavior is a question of concern. The difference in the saving pattern of students is also another question so this study is an attempt to address these questions. This study will be helpful for different banks and other financial institutions, policy makers and parents in getting the most appropriate information about the university level students.

2. Literature Review Saving is the partition of the income which was not spent on current consumptions (Ahmed, 2015; Cheema et al., 2018). The people save their money for different purposes. Saving is beneficial not only for the individuals but also for the whole country and it helps in infrastructure development and long-run investments in the country likewise saving act as a hurdle for countries against financial crisis and economic downturns (Jagadeesh, 2015; Baidoo et al., 2018). Clark and Madeleine (2008) demonstrated that financial literacy and financial plans are extremely successful in defeating the reduction in saving. The association between financial illiteracy and miss management of different financial matters may be obvious. The Theory of Planned Behavior supports the idea that financial literacy and parents are playing an important role in shaping the financial habits of individuals. In Theory of Planned Behavior, Ajzen (1991) stated that the behavior of the individuals influenced by their intentions formed by attitude, subjective norm and perceived behavioral control. 
Hogarth (2002) defined financial literacy as it is the way that how individuals managed their financial resources in the form of investment, insurance, budgeting, and saving. Financial literacy is an expertise or skill that can help individuals to make an effective financial decision. The individual's way of managing and saving behavior changed due to financial literacy. It describes in some studies that the financial literacy act as the awareness of different financial ideas and capability to deal their financial issues (Hogarth, 2002). Due to financial literacy, the individuals can get several benefits. Monticone (2012) argue that there are three main advantages of financial literacy. First, it enhances the attractiveness of different financial products and services, and also the capacity to utilize. Thus, this can increase the demand for these financial items. Second, due to financial literacy, the individuals can better manage their resources. Third, money related education can engage helpless people to effectively oversee and grow a small-scale business, enhancing their administrative abilities and the proper utilization of financial items for their organizations. Individuals who have financial information, aware about different financial threats and opportunities and the individuals who are conscious about their duties and rights in connection to monetary foundations can facilitate in developing the financial markets.

Beal and Delpachtra (2003) analyzed the financial knowledge of the university students in Australia and they found that financial literacy of business students is better as compared with others. They further argued that the Individuals who had higher financial literacy were better able to manage their money, make proper planning, decrease their spending and also invest more than others. Murphy (2005) documented that the majority of business student have more financial literacy than the non-business students and the students who belong to educated families are also more financially literate than the students who belong to a less educated family. Lusardi and Mitchell (2007) noted that an increase in the capabilities and financial knowledge help in promoting the effective decision-making in different financial matters, therefore, it enables the individuals to effectively manage their different life events such as schooling, illness, purchasing, and retirement.

There is practical evidence that parents can build up the skills of their kids that are imperative for savings. Furnham (1999) studied the habit of savings and spending of youngsters. He argued that saving behavior of young people is caused by parental requirements and requests. Parents can play a significant role in encouraging their kids toward savings (Lusardi\& Mitchell, 2014). There are two types of parents. First, the parents who always try to protect their kids from different financial difficulties and responsibilities. Such types of parents do not involve their kids in different financial matter discussions. Second, there are some parents who try to educate their children about the different financial matters because they know that it is important for them to know about it to manage their budget and also to increase their savings (Leiser \& Ganin, 1996; Ribeiro, Fonseca, \& Soares, 2018).

Homan (2016) argued that the parental education and socialization can help out in boosting the saving of individuals and decrease their borrowing. The saving habits of individuals can be developed when parents teach their kids during childhood. The parent's discussion of financial matters and guidance affect the saving and borrowing habits of their kids. The bad habits of children already formed if the parents start financial teaching too late. Parents can control the spending of their children by monitoring their expenditure regularly (Fatoki, 2014; Batty, Collins \& Odders-White, 2015). Wong (2013) stated that the individuals whose financial habits monitored by their parents during childhood had effectively managed their own money.

Based on the literature, we hypothesize that:

$\mathbf{H}_{1}$ : There is a positive relationship between parental socialization and saving behavior.

$\mathbf{H}_{2}$ : There is a positive relationship between financial literacy and saving behavior 
Figure 1: Research Model

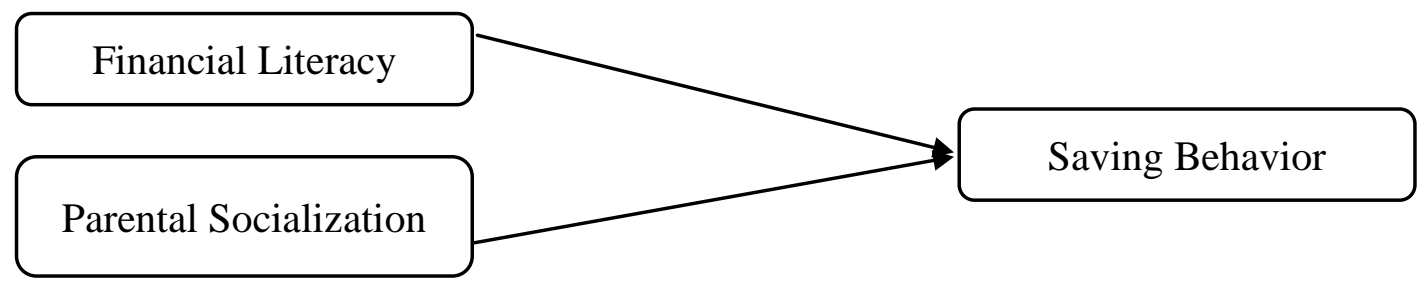

Source: Adapted from Thung et al. (2012)

\section{Methodology}

This is an explanatory study on the factors influencing the saving habits of university students in Pakistan.This is cross-sectional study in which the data was collected at one time from the university level students of Azad Jammu \& Kashmir, Pakistan. The target population for this study was all the students who were enrolled in different universities of Azad Jammu \& Kashmir. For this study, 400 students of Master of Business Administration were selected as samples from four universities of Azad Jammu \& Kashmir. By using the quota sampling technique, 100 samples were selected from each university including the University of Poonch Rawlakot, University of Kotli Azad Jammu and Kashmir, Mirpur University of Science and Technology and the University of Azad Jammu and Kashmir, Muzaffarabad. In this study, primary data was collected using questionnaires. Pearson correlation and multiple regression analysis was applied using SPSS. The following regression model was applied for empirical analysis:

$$
S B=\beta_{i}+\beta_{1} F L+\beta_{2} P S+€
$$

\subsection{Results and Discussion}

Table 1: Descriptive Statistics

\begin{tabular}{|l|l|l|l|l|l|}
\hline & $\mathrm{N}$ & Minimum & Maximum & Mean & $\begin{array}{l}\text { Std. } \\
\text { Deviation }\end{array}$ \\
\cline { 2 - 6 } & Statistic & Statistic & Statistic & Statistic & Statistic \\
\hline Gender & 391 & 1.00 & 2.00 & 1.3990 & .49032 \\
\hline Age & 391 & 1.00 & 5.00 & 3.5575 & .98248 \\
\hline Monthly Allowance & 391 & 1.00 & 5.00 & 2.5396 & 1.28615 \\
\hline Part-time Job & 391 & 1.00 & 2.00 & 1.8849 & .31954 \\
\hline FL & 391 & 1.00 & 5.00 & 3.4848 & 1.03632 \\
\hline PS & 391 & 1.00 & 5.00 & 3.7081 & .88277 \\
\hline SB & 391 & 1.00 & 5.00 & 3.6995 & .74211 \\
\hline
\end{tabular}

The above table shows that saving behavior has the highest mean score of 3.699; while gender has the lowest mean score of 1.399. For standard deviation, monthly allowance has the highest score of 1.286; whereas .3195 is the lowest value scored by part-time job.

Correlations

\begin{tabular}{|ll|l|l|l|}
\hline & & FL & PS & SB \\
\hline FL & Pearson Correlation & 1 & & \\
& Sig. (2-tailed) & & & \\
& N & 391 & & \\
\hline PS & Pearson Correlation & $.657^{* *}$ & 1 & \\
& Sig. (2-tailed) & .000 & & \\
& N & 391 & 391 & \\
\hline SB & Pearson Correlation & $.498^{* *}$ & $.567^{* *}$ & 1 \\
& Sig. (2-tailed) & .000 & .000 & \\
\hline
\end{tabular}




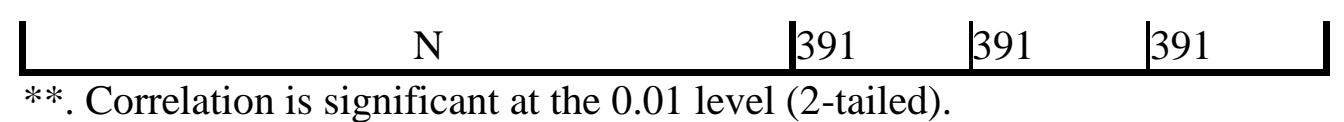

The above table shows that the financial literacy and parental socialization both have a positive association with saving behavior of university level students. The parental socialization has strong $(r=$ $0.567)$ relationship with the saving behavior of university level students while financial literacy has $(r=$ 0.498 ) association with saving behavior. The relationship between parental socialization with financial literacy is stronger in comparison with other because the financial literacy level of individuals not only increase due to getting financial education but also due to parent's guideline and encouragement.

\section{Table 3: Multiple Regression Analysis}

Saving Behavior

\begin{tabular}{|c|c|c|c|c|c|}
\hline Predictors & Beta & $\mathrm{t}$ & & $\mathrm{R}^{2}$ & $\Delta \mathrm{R}^{2}$ \\
\hline \multicolumn{6}{|l|}{$\underline{\text { Step } 1}$} \\
\hline \multicolumn{6}{|l|}{ Control Variable } \\
\hline Age & & 4.359 & & & \\
\hline Monthly Allowance & & 4.489 & & $.129 * *$ & .125 \\
\hline \multicolumn{6}{|l|}{$\underline{\text { Step } 2}$} \\
\hline \multicolumn{6}{|l|}{ Direct Effect } \\
\hline Financial Literacy & $0.153 * *$ & 4.163 & & & \\
\hline Parental Socialization & $0.322 * *$ & 7.412 & .422 & & .416 \\
\hline
\end{tabular}

Note. $* * \mathrm{p}<.01$

Table above indicates 0.422 value of R square which means that FL and PS explained $42.2 \%$ variation in the saving behavior of university-level students. In regression analysis, the F-value is 70.435 which shows the fitness of model in this study. The above results revealed that the parental socialization $(\beta=0.322)$ has a strong influence on SB this means that by holding other variables constant, an increase in the unit of PS will result in 0.322 units increase in the SB, therefore H1 is accepted. Similarly the FL $(\beta=0.153)$ has second strong influenced on SB and it is also show that if one unit of FL will increase then .153 units of $\mathrm{SB}$ will increase, thus, $\mathrm{H} 2$ is accepted also.

\section{Conclusion}

This study aimed to analyze the impact of FL and PS on the SB of university-level students in AJ\&K, Pakistan. The results of this study demonstrate that the FL and PS both have positive impact on SB of university-level students. Our result revealed that the students who have financial literacy exhibit more saving behavior as compared to others who do not have financial knowledge. It is also concluded that the student willingness to save increased due to receiving financial education from their parents (Fatoki, 2014; Mahdzan \& Tabiani, 2013). The parents are the best source who can control the spending of their kids and can encourage them for savings. So both FL and PS positively influence the savings of individuals which not only increase their financial resources but also beneficial for the whole economy because an increase in the savings will help in infrastructure development and long-run investments in the country and it will directly influenced on GDP and finally affect the economic growth of the countries (Cheema et al., 2018).

This study will provide direction to policy makers and other regulating authorities to make appropriate strategies to increase the saving of youngsters. They need to organize different financial training programs to increase the financial literacy of students. This study will help different banks to gain better understanding of saving behavior of university level students of AJ\&K. Therefore they can develop financial products or services according to the needs and preferences of university students to convert 
these students as their valuable customers. In this study, parental socialization is a good predictor of their children's saving behavior. Parents always play the central role in facilitating and promoting their children's saving behavior. This study will enable the parents to get the information about the financial behavior of their children and so due to this they can be able to control their spending and can encourage them for savings.

\section{References}

Ahmad, F. (2015). Determinants of savings behavior in Pakistan: Long run-short run association and causality. Timisoara Journal of Economics and Business, 8(1), 103-136.

Ajzen, I. (1991). The theory of planned behavior. Organizational Behavior and Human Decision Processes, 50(2), 179-211.

Akhtar, S. (1987). Dependency, urbanization, education and household saving; some preliminary evidence from Pakistan saving and development. Giordano Dell-Amore Foundation 11(4), 337353. Retrieved October, 26, 2015, from http://www.jstor.org/stable/25830124

Ali, A. (2016). SBP Staff Notes. [online] Available at: http://www.sbp.org.pk/publications/staffNotes.htm [Accessed 14 Oct. 2017].

Auerbach, A. J., \& Kotlikoff, L. J. (1983). National savings, economic welfare, and the structure of taxation. In Behavioral simulation methods in tax policy analysis (pp. 459-498). University of Chicago Press.

Ayadi, M. A., Ben Omrane, W., Lazrak, S., \& Yang, J. (2018). The Dynamics of Currency, Savings, and Investment Rates. International Review of Finance, 18(1), 3-33.

Azhar, A. B. (1995). Rural savings their magnitude, determinants, and mobilization. The Pakistan Development Review, 34(4), 779-788.

Baidoo, S. T., Boateng, E., \&Amponsah, M. (2018). Understanding the determinants of saving in Ghana: Does financial literacy matter? Journal of International Development.

Batty, M., Collins, J. M. and Odders-White E. (2015). Experimental evidence on the effects of financial education on elementary school students' knowledge, behavior and attitudes. Journal of Consumer Affairs, 49(1), 69-96.

Beal, D. J., Delpachtra, S. B. (2003). Financial literacy among Australian university students. Economic Papers, 22 (1), 65-78.

Browning, M., \& Crossley, T. F. (2001). The life-cycle model of consumption and saving. Journal of Economic Perspectives, 15(3), 3-22.

Cheema, A. R., Saleem, A., ur Rehman, A., \& Atif, M. (2018). Assessing the Determinants of Savings in Pakistan: An Evidence from PSLM 2010-11. European Online Journal of Natural and Social Sciences, 7(2), pp-366.

Domar, E. (1946). Capital expansion, rate of growth, and employment. Econometrica, 14(2), 137-147.

Fatoki, O. (2014). The Financial literacy of non-business university students in South Africa. International Journal of Educational Sciences, 7(2), 261-267.

Furnham, A. (1999). The saving and spending habits of young people. Journal of Economic Psychology, 20(6), 677-697.

Gedela, P. (2012). Determinants of saving behavior in rural and tribal households: an empirical analysis of Visakhapatnam District. International Journal of Research in Social Sciences, 2(3), 108-128.

Harrod, R. (1939). An essay in dynamic theory. The Economic Journal, 49(193), 14-33.

Hogarth, J. M. (2002). Financial literacy and family and consumer sciences. Journal of Family and Consumer Sciences, 94(1), 15-28.

Homan, A. M. (2016). The influence of parental financial teaching on saving and borrowing behavior. Unpublished master's thesis, University of University of Groningen.

Iqbal, Z. (1993). Institutional variations in saving behavior in Pakistan. The Pakistan Development Review, 32, 1293-1311.

Jagadeesh, D. (2015). The impact of savings in economic growth: an empirical study based on Botswana. International Journal, 10. 
Khan, A. H., Hasan, L., Malik, A., \& Knerr, B. (1992). Dependency ratio, foreign capital inflows and the rate of savings in Pakistan. The Pakistan Development Review, 31(4), 843-856.

Lusardi, A. \& Mitchell, O.S. (2007) Baby Boomer retirement security: the roles of planning, financial literacy, and housing wealth. Journal of Monetary Economics, 54, 205-224.

Lusardi, A. and Mitchell, O. S. (2014). Financial literacy and retirement preparedness: evidence and implications for financial education. Business Economics, 42(1), 35-44.

Lusardi, A. and Mitchell, O. (2014). The economic importance of financial literacy: Theory and evidence. Journal of Economic Literature, 52(1), 5-44.

Nasir, S., Khalid, M., \&Mahmood, A. (2004). Saving-investment behaviour in Pakistan: An empirical investigation [with Comments]. The Pakistan Development Review, 665-682.

Murphy, A. J. (2005). Money, money, money: An exploratory study on the financial knowledge of Black college students. College Student Journal, 39(3), 478-488.

Mahmood, Z., and M. A. Qasim (1992) Foreign Trade Regime and Savings in Pakistan. The Pakistan Development Review 31:4, 883-893.

Mahdzan N.S, \& Tabiani, S (2013). The impact of financial literacy on individual saving: an exploratory study in the Malaysian context. Transformation in Business and Economics. Vol. 12 No. (28) pp 41-55

Ribeiro, R. B., Fonseca, J. R., \&Soares, I. (2018). Spend as I say, not as I do: Children, families and household consumption in different socio-economic contexts. International Journal of Consumer Studies, 42(5), 566-582.

Salikin, N., Wahab, N., Zakaria, N., Masruki, R., \& Nordin, N. (2012). Students' saving attitude: does parents' background matter? International Journal of Trade, Economics and Finance, 3(6), 479484.

Sarpong-Danquah, B., Gyimah, P., Poku, K., \&Osei-Poku, B. (2018). Financial Literacy Assessment on Tertiary Students in Sub-Saharan Africa: A Ghanaian Perspective. International Journal of Accounting and Financial Reporting, 8(2), 76-91.

Thung, C., Kai, C. Y., Nie, F. S., Chiun, L. W., \& Tsen, T. C., (2012). Determinants of saving behavior among the university students in Malaysia. Unpublished master's thesis, University Tunku Abdul Rahman.

Wong, B. A. (2013). Practices of savings among students. Unpublished master's thesis, University of Malaysia Sarawak, Malaysia. 
